\title{
Synthesis of water-soluble chitosan inhibitor from shrimp shells and its corrosion rate on mild steel in acidic solution
}

\author{
Nur Layli Amanah ${ }^{1, b)}$, Ika Dyah Widharyanti ${ }^{1}$, Agung Nugroho ${ }^{1, a)}$ \\ ${ }^{1}$ Department of Chemical Engineering, Universitas Pertamina, Jalan Teuku Nyak Arief, \\ Simprug, Kebayoran Lama, Jakarta 12220, Indonesia \\ a)Agung.n@universitas pertamina.ac.id, b)nurlayli78@gmail.com
}

Received 14 January 2021, Revised 29 February 2021, Published 30 March 2021

\begin{abstract}
Synthesis of WSCI (Water Soluble Chitosan Inhibitor) from shrimp shell waste is carried out through demineralization, deproteination, and deacetylation processes. WSCI is obtained from monomer termination and $\mathrm{H}_{2} \mathrm{O}_{2}$ assistance. WSCI was characterized using Fourier Transform Infrared Spectroscopy (FTIR) and the degree of deacetylation was determined using the baseline method. The effect of adding WSCI to low carbon steel SS400 with a $1 \mathrm{M} \mathrm{HCl}$ corrosive environment was studied using the weight loss method at various concentrations and temperatures. The overall results of the research show that WSCI synthesis used in the prevention of corrosion have an inhibition efficiency of up to $74.6 \%$ at a concentration of $200 \mathrm{ppm}$ at a temperature of $28^{\circ} \mathrm{C}$. Inhibition efficiency and corrosion rate are known to increase with increasing WSCI concentration and corrosion rate decreasing with increasing temperature.
\end{abstract}

Keyword : Corrosion, Inhibitor, Water Soluble Chitosan, Shrimp Shell

\section{Introduction}

Carbon steel is widely used in industry because of the ease of construction, relatively low cost, and its raw materials are abundant in nature. In the past decade, world carbon steel production continued to increase due to increasing in consumption of carbon steel which varied depend on quality needs. Qualifications based on the percent of carbon and microstructure can be divided into 3, low carbon steel, medium carbon steel, and high carbon steel. For industrial needs, mild steel types such as SS400 structural steel are generally used. It is soft, ductile, malleable, designed for a long term service, and with a maximum carbon content of $0.2 \%$ (Riskin, 2008). This steel can be found on wire rod, ship plates, storage tanks, heat exchangers, transportation pipes, stelmor line, and so on (Wiewiórowska \& Muskalski).

In reality, carbon steel is susceptible to corrosion. Corrosion attacks the surface film layer of carbon steel caused by decreased $\mathrm{pH}$, environmental alkalinity, or acidic ion (Arwati, 2018). For example, in surface facility pipelines, surface erosion will result in a type of pitting corrosion. The main cause is fluid flow which has more than two mixed phases. If not handled properly, corrosion will cause damage to failure. There are several methods to overcome corrosion, one of which is the addition of an inhibitor. Inorganic inhibitors such as nitrite chromate, zinc salt and polyphosphate are often found in industry (Makhlouf \& Botello, 2018). Of the many inhibitors, Chromate shows the best results for 
metal plating. However, these inhibitors are classified as dangerous which can cause health problems and environmental pollution (El-Enin \& Amin, 2020).

For this reason, an inhibitor that is more environmentally friendly (green inhibitor) is needed. For now, the green inhibitor with the highest inhibition efficiency (EI) in protecting mild steel is found in Azadirachta indica which reaches $98 \%$. In addition, there are also Poinciana pulcherrima Cassia occidentalis with EI 96\%, Pongamia glabra 8995\% (Sakthivel et al., 1999) and Acacia arabica 93-97\% (Shehata et al., 2018). Chitosan as a derivative of chitin compounds can actually be used in the prevention of corrosion (Saleh et al., 2017). One of the drawback is that chitosan is insoluble in water (Kahya, 2018). These can limit the application of chitosan as corrosion inhibitor which mostly in aqueous solution.

In this work, chitosan as a green inhibitor will be converted into water soluble chitosan inhibitor (WSCI) by adding a hydroxyl group. WSCI synthesis is carried out through the process of demineralization, deproteination, deacetylation, and changing the deacetylation product (chitosan). Fourier Transform Infrared Spectroscopy (FTIR) was done to confirm the functional group during synthesis. Moreover, the performance of the WSCI can be seen through the corrosion test with the weight reduction method on the SS400. The surface morphology of SS400 was determined by optical microscopy and Scanning Electron Microscopy (SEM) after immersion in the $1 \mathrm{M} \mathrm{HCl}$ environment.

\section{Method}

\subsection{WSCI Synthesis}

Shrimp shells were cleaned with running water for 3 times, drained and dried at a temperature of $150{ }^{\circ} \mathrm{C}$ for 4 hours. The dry shells are mashed and weighed for 50 grams as the initial sample. In the demineralization stage, the initial sample was heated at 60-70 ${ }^{\circ} \mathrm{C}$ with the addition of $\mathrm{HCl} 500 \mathrm{ml} \mathrm{1:10} \mathrm{(w/v)} \mathrm{for} 4$ hours and stirred at $50 \mathrm{rpm}$. The samples were decanted and washed with distilled water until the $\mathrm{pH}$ became neutral. The drying process was carried out at $60{ }^{\circ} \mathrm{C}$ for 8 hours and then weighed. Crude chitin is reacted with $\mathrm{NaOH} 3.5 \% 1: 10(\mathrm{w} / \mathrm{v}$ ) between the solvent and the sample in the deproteination process. The mixture was stirred and heated at a temperature of $60-70{ }^{\circ} \mathrm{C}$ for 1 hour with a stirring speed of $300 \mathrm{rpm}$. The samples were decanted and dried at 60 ${ }^{\circ} \mathrm{C}$ for 8 hours. Chitin was weighed and characterized by FTIR.

Deacetylation, the conversion of chitin to chitosan was carried out by adding $60 \%$ $\mathrm{NaOH}$ (ratio of chitin weight: volume of $\mathrm{NaOH}, 1: 10(\mathrm{w} / \mathrm{v})$ ). The mixture was stirred and heated at $60-70{ }^{\circ} \mathrm{C}$ for 1 hour with a stirring speed of $300 \mathrm{rpm}$ and decantation was carried out. The washing process with distilled water was carried out until it reached a neutral $\mathrm{pH}$. Chitosan was dried at $60{ }^{\circ} \mathrm{C}$ for 8 hours. Dry chitosan was weighed and characterized by FTIR instrument.

The deproteinated chitosan was then converted into water-soluble chitosan by adding $2 \%$ acetic acid with the ratio of 1:10 (w/v). Stirring $140 \mathrm{rpm}$ and heated to a sample temperature of $40{ }^{\circ} \mathrm{C}$ for 4 hours. $\mathrm{H}_{2} \mathrm{O}_{2}$ was added to the sample with the ratio of $1: 4$ (w / v). The sample turned into a filtrate with an acidic $\mathrm{pH}, 10 \% \mathrm{NaOH}$ was added until the $\mathrm{pH}$ became neutral. The filtrate was cooled and acetone solvent was added twice the 
volume of the filtrate. Samples are incubated for 10-12 hours until solids are formed. The solids obtained were separated from the solvent and dried in an oven at $50{ }^{\circ} \mathrm{C}$ for 8 hours before they were cooled in a desiccator. The obtained WSCI was weighed and then characterized by FTIR.

\subsection{Characterization}

The method of analyzing the characteristics of the research was carried out using the FTIR, Thermo Scientific Nicolet IS5 Mid-Infrared FT-IR Spectrometer with KBR which was used for deproteination and deacetylation testing in the process of making chitosan.

\subsection{Specimen Preparation}

Mild steel SS400 $(2.5 \times 2.5 \times 0.5) \mathrm{cm}$ is cleaned using a grinding machine with sandpaper $(120,400,600,800$, and 1000) grid. It is washed with ethanol and dried at a temperature of $50-60{ }^{\circ} \mathrm{C}$ for 15 minutes. Weigh it as initial weight $\left(\mathrm{w}_{\mathrm{o}}\right)$.

\subsection{Weight Loss Measurement}

Immerse SS400 in $100 \mathrm{ml}$ of $1 \mathrm{M} \mathrm{HCl}$ with the addition of WSCI $(0,50,100$, and 200) ppm for $(24,48$, and 72$)$ hours. Washing and drying processes are carried out after immersion in order to weigh the final weight $(\mathrm{w})$. The calculation of the corrosion rate is determined by the equation:

$$
\text { Corrosion Rate }=\frac{K \times W}{D \times A \times t}
$$

Where $\mathrm{K}$ is a constant $\left(8.76 \times 10^{4} \mathrm{~mm} /\right.$ year $), \mathrm{W}$ is the weight loss $(\mathrm{g}), \mathrm{D}$ is the density of the metal $\left(\mathrm{g} / \mathrm{cm}^{3}\right), \mathrm{A}$ is the surface area of the corroded metal $\left(\mathrm{cm}^{2}\right)$, and $\mathrm{t}$ is the duration of immersion (hour).

Inhibition efficiency is the determination of the corrosion rate effectively. The calculation of inhibition efficiency can be determined by:

$$
\text { Inhibition Efficiency }=\frac{X a-X b}{X a} \times 100 \%
$$

Where $X_{a}$ is the corrosion rate without using an inhibitor ( $\mathrm{cm} /$ year), and $X_{b}$ is the corrosion rate using an inhibitor $(\mathrm{cm} /$ year)

Sample yield calculation:

$$
\% \text { yield }=\frac{\text { Sample weights results }}{\text { Initial sample weights }} \times 100 \%
$$

\subsection{Morphological Test}

The morphological test was carried out to determine the surface structure of SS400 carbon steel before and after immersion or to determine the effect of inhibitors on the corrosion rate. This morphological test was carried out with an ZEISS ZEN Microscope and Phenom Pro-X Pharos Desktop Scanning Electron Microscope. 


\section{Result and Discussion}

\subsection{Demineralization}

The impurity content of shrimp shells in the form of $\mathrm{CaCO}_{3}$ and $\mathrm{Ca}_{3}\left(\mathrm{PO}_{4}\right)_{2}$ is $45-50 \%$ (Mursida, 2018). The loss of $\mathrm{CaCO}_{3}$ and $\mathrm{Ca}_{3}\left(\mathrm{PO}_{4}\right)_{2}$ minerals are assisted by an acid solution by changing the color of the solution which turned blackish brown and formed $\mathrm{CO}_{2}$ gas.

$$
\begin{gathered}
\mathrm{CaCO}_{3}(\mathrm{~s})+2 \mathrm{HCl} \rightarrow \mathrm{CaCl}_{2}(l)+\mathrm{CO}_{2}(g)+\mathrm{H}_{2} \mathrm{O}(l) \\
\mathrm{Ca}_{3}\left(\mathrm{PO}_{4}\right)_{2}(s)+6 \mathrm{HCl}(\mathrm{l}) \rightarrow 3 \mathrm{CaCl}_{2}(l)+2 \mathrm{H}_{3} \mathrm{PO}_{4}(l)
\end{gathered}
$$

The final sample mass obtained in this demineralization process was 11.867 grams. So that the yield obtained reached $23.73 \%$.

\subsection{Deproteination}

Proteins that are covalently bound to chitin compounds will dissolve in alkaline solvents. The base used has a concentration limit that is allowed, if it exceeds, it will trigger a deacetylation reaction (Kumari et al., 2015). Stirring and heating are carried out, none other than in order to speed up the process of binding the ends of the protein chain with $\mathrm{NaOH}$, so that the protein settles completely. Physically, there is a thickening during the reaction, which is caused by the formation of sodium proteinate (Dompeipen, 2017). The final weight obtained from the deproteination process is 5.6623 grams. So that the yield resulting from the deproteination process reached $50.32 \%$.

$$
\begin{aligned}
\mathrm{R}-\mathrm{CH}\left(\mathrm{NH}_{2}\right) & -\mathrm{COO}^{-}(\mathrm{s})+\mathrm{NaOH}(\mathrm{aq}) \\
& \rightarrow \mathrm{R}-\mathrm{CH}\left(\mathrm{NH}_{2}\right)-\mathrm{COONa}(\mathrm{aq})+\mathrm{H}_{2} \mathrm{O}(\mathrm{g})
\end{aligned}
$$

\subsection{Deacetilation}

Deacetylation is the stage of converting chitin into chitosan through the hydrolysis process (Kaczmarek et al., 2019). The chitin compound undergoes removal of the acetyl group from $\left(-\mathrm{NHCOCH}_{3}\right)$ which is replaced by an amine group $\left(-\mathrm{NH}_{2}\right)$ in the chitosan compound through the addition of a concentrated base, $\mathrm{NaOH} 60 \%$. The final weight of deacetylation results shows the number 2.8966 grams. So that the yield obtained is $51.16 \%$.

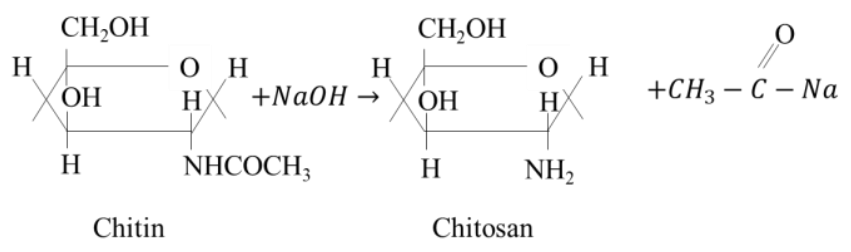

Chitosan synthesis is success if DD (deacetylation degree) value of more than $50 \%$ by drawing a baseline on the FTIR graph of chitosan compounds (Salas et al., 2017). In this experiment DD value obtained is $53.28 \%$. This value indicate that chitosan synthesis was successful. 


\subsection{Converting Chitosan into WSCI}

The stages of converting chitosan into WSCI with the help of $\mathrm{H}_{2} \mathrm{O}_{2}$ are based on environmentally friendly reasons and the safe nature of $\mathrm{H}_{2} \mathrm{O}_{2}$ from the resulting residue. $\mathrm{H}_{2} \mathrm{O}_{2}$ has a role in producing carboxyl groups and accelerating the deamination process (chitosan depolymerization). The role of $\mathrm{H}_{2} \mathrm{O}_{2}$ is to produce $\mathrm{HOO}^{-}$anion which is very unstable and will turn into a highly reactive hydroxyl radical.

The preparation of WSCI depends on increasing the concentration of $\mathrm{H}_{2} \mathrm{O}_{2}$. The higher the concentration of $\mathrm{H}_{2} \mathrm{O}_{2}$ added, the higher the solubility level of WSCI will be. The high solubility is supported by the breaking of the glycosidic bonds in chitosan, so that the final molecular weight of the WSCI compound will be lighter (Chamidah et al., 2019). The event that occurs is that $\mathrm{H}_{2} \mathrm{O}_{2}$ will break down into radical hydroxyl groups, with the following mechanism:

$$
\begin{aligned}
\mathrm{HOO}^{-} & \rightarrow \mathrm{OH}^{-}+\mathrm{O}^{\mathbf{}} \\
\mathrm{H}_{2} \mathrm{O}_{2}+\mathrm{HOO}^{-} & \rightarrow \mathrm{HO}^{\mathbf{-}}+\mathrm{O}^{2-}+\mathrm{H}_{2} \mathrm{O}
\end{aligned}
$$

The reaction takes place very rapidly when it encounters polysaccharides, or by attacking hydroxyl radicals on the glycosidic bonds of chitosan. The breaking of the glycosidic bonds takes place by binding to $\mathrm{H}$ atoms and forming water, so that in the end water-soluble oxidation occurs and produces WSCI in the form of a filtrate.

Based on the FTIR graph in Figure 1, the wave numbers 3589 and $3394 \mathrm{~cm}^{-1}$ indicate the presence of vibrations of the $-\mathrm{OH}$ and $-\mathrm{NH}_{2}$ groups in the chitin compound. After conversion chitin to chitosan the $\mathrm{NH}$ group have the higher intensity due to the addition of $\mathrm{NH}_{2}$ in the reaction seven. The bands due to $\mathrm{NH}$ of the amide group at $3118 \mathrm{~cm}^{-1}$ in chitin are disappearing in chitosan (Velde \& Kiekens, 2004). The peaks due to - $\mathrm{CH}$ functional group are observed at $2928 \mathrm{~cm}^{-1}$ and $2869 \mathrm{~cm}^{-1}$ for chitin and chitosan, which slightly weak in WSCI. The band at $1659 \mathrm{~cm}^{-1}$ in chitin which was attributed to CO amide group also show decreasing in intensity on chitosan and WSCI, while the band at 1566 $\mathrm{cm}^{-1}$ show slightly increase on the conversion from chitosan to WSCI.



Figure 1. FTIR Spectra of Chitin, Chitosan, and WSCI. 


\section{Corrosion Test}

The WSCI corrosion test was carried out at three different concentrations 50, 100, 200 ppm by comparing the blanks. So that the inhibition efficiency increases along with the increasing of WSCI concentration. The highest inhibition efficiency value reached $74.6 \%$ at a concentration of $200 \mathrm{ppm}$. The increase in the value of inhibition efficiency shows that the surface coverage has increased from the inhibitor molecules adsorbed on the surface of mild steel. Surface coverage is the number of amine molecules present on the metal surface after the addition of an inhibitor. Temperature is a parameter to determine the metal dissolution process and to assess the stability of the WSCI film formed on the carbon steel surface. Obviously, the figure 2 shows that the height of the test temperature increases, the inhibition efficiency obtained will decrease due to metal dissolution and desorption inhibitors. This is reinforced by a picture showing an increase in the corrosion rate with increasing temperature.

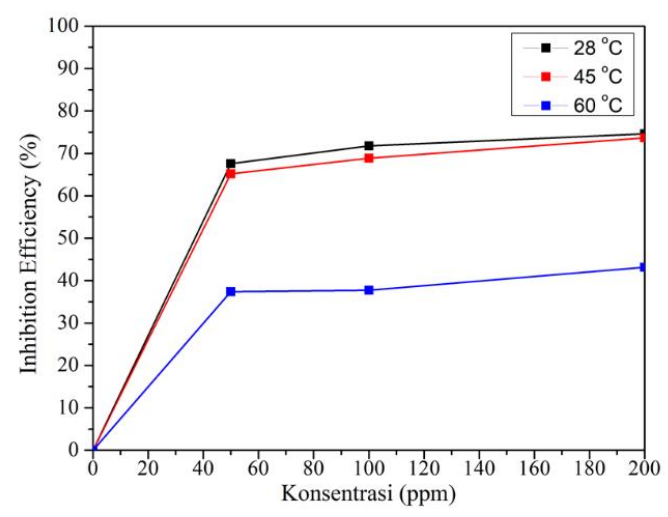

(a)



(b)

Figure 2. Concentration vs Inhibition Efficiency (a) Temperature vs Inhibition Efficiency and (b) Corrosion Rate.

\section{Mild Steel Surface Morphology Test Results}

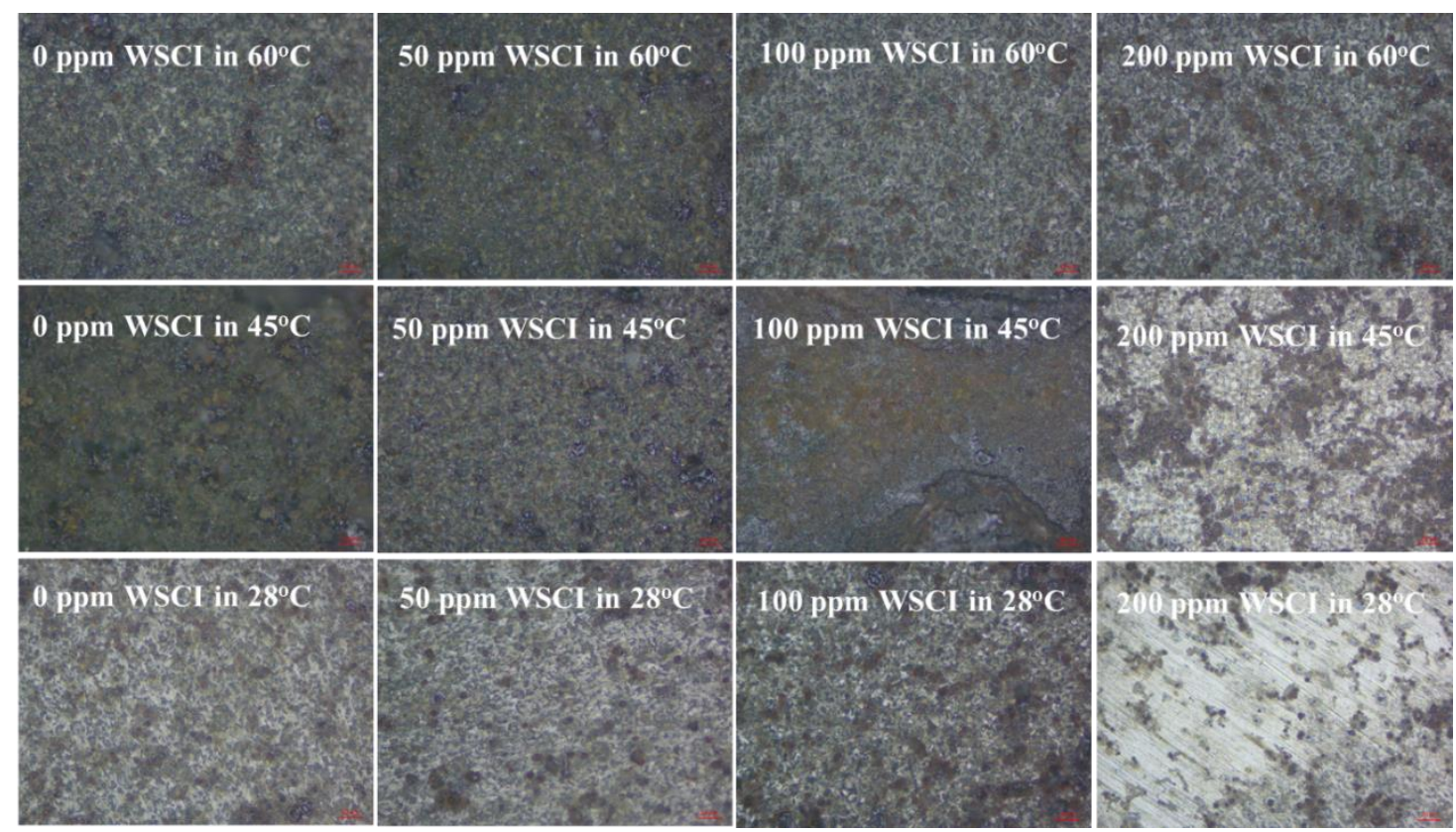

Figure 3. The results of optical microscope test on various temperature and various concentration of WSCI. 
Macro test (Figure 3) with an optical microscope cannot clearly show the corroded part. However, it can compare between treatments with one another. From the picture it is clear that the lighter part of the carbon steel is the part of the iron that is free from corrosion, which is not coated with an oxide layer. Meanwhile, black spots indicate corrosion products in the form of pitting corrosion. The greater the concentration of WSCI that is added, the black spots as an indication of corrosion will decrease. However, with increasing temperature, black spots were found spread over almost the entire surface of the SS400.

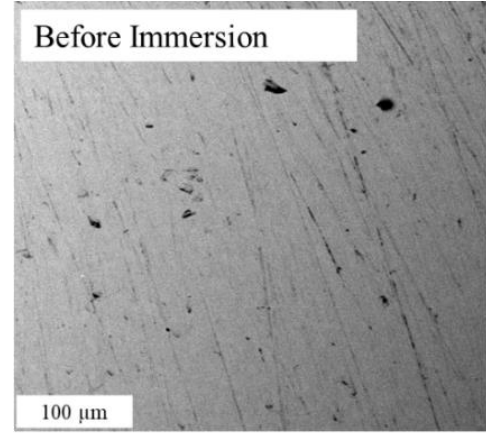

(a)



(b)



(c)

Figure 4. surface of SS400 before immersion (a) Surface of SS400 after immersion with the addition of $200 \mathrm{ppm}$ WSCI (b) Layer of film on the surface of SS400 with the addition of $200 \mathrm{ppm}$ WSCI.

Secondary electron analysis generated by SEM resulted in the topography of the sample being tested. The image results from SEM show differences in dark and light colors due to differences in surface height. In Figure 4 (a), the surface of the SS400 is mostly light colored and there are black spots. This hole defect will trigger the acceleration of corrosion. In Figure 4 (b), the surface of the SS400 is dark and indicates the type of pitting corrosion. this shows the corrosion resistance of the WSCI film coating in Figure 4 (c). Figure 4 (c) shows the presence of a film layer formed by the addition of WSCI which is hydrophobic (Dwivedi et al., 2017; Hajji et al., 2014). These film layers are bonded to each other to cover the entire surface of the SS400.

\section{Conclusion}

Based on the discussion that has been described, it is concluded that the DD value of WSCI (Water Soluble Chitosan Inhibitor) synthesis from shrimp shell waste is $53.28 \%$, the addition of WSCI can reduce the corrosion rate of SS400 carbon steel with the best concentration of $200 \mathrm{ppm}$ using the weight reduction method. In addition, the resulting inhibition efficiency of WSCI has decreased and the rate of corrosion has increased with the addition of operating temperature, and the optimum resistance efficiency is $74.61 \%$ at a temperature of $\pm 28{ }^{\circ} \mathrm{C}$.

\section{Acknowledgements}

The author is very grateful to the Chemical Engineering Laboratory and Mechanical Engineering Laboratory of Universitas Pertamina for the support of this research. 


\section{References}

Arwati, I.G.A. (2018). Effect of Chitosan on the Corrosion Protection of Aluminum in H2SO4 medium, World Chem Eng J, 2 pp.1-5, 2018.

Chamidah, A. C.N. Widiyanti, N.N. Fabiyani, (2019), Utilization of Water-Soluble Chitosan as Antiseptic Hand Sanitizer, J Perikan Univ Gadjah Mada, 21 pp.916.

Dompeipen, E.J. (2017). Isolasi dan identifikasi kitin dan kitosan dari kulit udang Windu (Penaeus monodon) dengan spektroskopi inframerah, Maj Biam, 13 pp.31-41.

Dwivedi, D. K. Lepková, T. Becker, (2017), Carbon steel corrosion: a review of key surface properties and characterization methods, $R S C A d v, 7$ pp.4580-4610.

El-Enin, S. Abo. \& A. Amin, (2020), Review of Corrosion Inhibitors for Industrial Applications, Int J Eng Res Rev, 3 pp.127-145, 2020.

Hajji, S. I. Younes, O. Ghorbel-Bellaaj, R. Hajji, M. Rinaudo, M. Nasri, K. Jellouli, (2014), Structural differences between chitin and chitosan extracted from three different marine sources, Int J Biol Macromol, 65 pp.298-306.

Kaczmarek, M.B. K. Struszczyk-Swita, X. Li, M. Szczęsna-Antczak, M. Daroch, (2019), Enzymatic modifications of chitin, chitosan, and chitooligosaccharides, Front Bioeng Biotechnol, 7 pp.243.

Kahya, N. (2018), Water soluble chitosan derivatives and their biological activities: a review, Polym Sci, 4 pp.1-16.

Kumari, S. P. Rath, A.S.H. Kumar, T.N. Tiwari, Extraction and characterization of chitin and chitosan from fishery waste by chemical method, Environ Technol Innov, 3 pp.77-85, 2015.

Makhlouf, A.S.H. M.A. Botello, (2018), Chapter 1 - Failure of the metallic structures due to microbiologically induced corrosion and the techniques for protection, in: A.S.H. Makhlouf, M.B.T.-H. of M.F.A. Aliofkhazraei (Eds.), Handb. Mater. Fail. Anal., Butterworth-Heinemann, pp. 1-18.

Mursida, M. T. Tasir, S. Sahriawati, (2018), Efektifitas Larutan Alkali pada Proses Deasetilasi dari Berbagai Bahan Baku Kitosan, J Pengolah Has Perikan Indones, 21 pp.356-366.

Riskin, J. (2008). Chapter 2 - Corrosion and Protection of Underground and Underwater Structures Attacked by Stray Currents, in: J.B.T.-E. and P. of M. Riskin (Ed.), Electrocorrosion Prot. Met., Elsevier, Amsterdam, pp. 23-35.

Sakthivel, P. P. V Nirmala, S. Umamaheswari, A.A.A. Antony, G. Paruthimal Kalaignan, A. Gopalan, T. Vasudevan, Corrosion inhibition of mild steel by extracts of Pongamia Glabra and Annona Squamosa in acidic media, Bull Electrochem, 15 pp.83-86, 1999.

Salas, C. Z. Thompson, N. Bhattarai, 15 - Electrospun chitosan fibers, in: M.B.T.-E.N. Afshari (Ed.), Electrospun Nanofibers, Woodhead Publishing, 2017: pp. 371398.

Saleh, C.W. H. Harmami, I. Ulfin, (2017), Pengendalian korosi menggunakan inhibitor kitosan larut air untuk baja lunak dalam media HCl 1M, J Sains Dan Seni ITS, 6 pp.C1-C4. 
Shehata, O.S. L.A. Korshed, A. Attia, (2018), Green corrosion inhibitors, past, present, and future, Corros Inhib Princ Recent Appl, pp.121.

Velde, K. Van de. P. Kiekens, (2004), Structure analysis and degree of substitution of chitin, chitosan and dibutyrylchitin by FT-IR spectroscopy and solid state 13C NMR, Carbohydr Polym, 58 pp.409-416.

Wiewiórowska, S. Z. Muskalski, (2015), The application of low and medium carbon steel with multiphase TRIP structure in drawing industry, Procedia Manuf, 2 pp.181185. 